\title{
SEASONAL CHANGES OF PHOTOPERIODIC RESPONSE AND INFLORESCENCE QUALITY IN POT CULTIVARS OF Chrysanthemum $\times$ grandiflorum GROWN IN GREENHOUSE
}

\author{
${ }^{1}$ Marek Jerzy, ${ }^{2}$ Włodzimierz Breś \\ ${ }^{1}$ Department of Ornamental Plants, Poznan University of Life Sciences, Dąbrowskiego 159, 60-594 Poznań, Poland \\ ${ }^{2}$ Department of Plant Nutrition, Poznan University of Life Sciences, Zgorzelecka 4, 60-198 Poznań, Poland \\ e-mail: wbnaw@up.poznan.pl
}

Received: 15.06.2011

\begin{abstract}
The aim of the research was to investigate seasonal changes of photoperiodic response and inflorescence quality in chrysanthemum from the Time group grown all year round without supplementary lighting. Four chrysanthemum cultivars were grown in 12 cycles starting on the second day of each successive month. The first cycle began on 2 January. From the moment of potting, the plants were treated with a short day. In periods of naturally long days, the day was shortened to 10.5 hours through shading. No supplementary illumination was used from November to mid-February (a photoperiod of under 10 hours) to improve light conditions in the period of insolation deficit. In Polish climatic conditions, the shortest photoperiodic responses were recorded usually in the cycles starting in February or March and August or September. An exceptionally longer photoperiodic response was recorded in the cycle including the height of summer, i.e. planting from June to July, when the temperature during the day was very high, and from October to December i.e. in the period of substantial insolation deficit. The highest quality of flower heads was attained by plants potted mostly between 2 March and 2 September and flowering from April - May to November. Those plants developed the greatest number of inflorescences and usually a typical, cultivar-specific colour of the flower. Chrysanthemums potted from 2 June to 2 July, i.e. in the period of the greatest heat, produced inflorescences with the smallest diameter. For the cultivar 'Cool Time', this unfavorable period lasted from 2 April to 2 August.
\end{abstract}

Key words: Chrysanthemum grandiflorum, Time group, AYR culture, flower heads.

\section{INTRODUCTION}

Chrysanthemum development depends on many factors. The most important ones include light conditions: photoperiod, light intensity, and light quality. During the year, each length of day (except for the shortest day in winter and the longest day in summer) occurs twice. Plant response in the period of day elongation in spring is different than plant response in the period of the increasingly shortest days in autumn. It is connected with different temperatures prevailing in spring and autumn. An effect of these dependencies is the changing photoperiodic response and quality of chrysanthemums grown all year round. Strong light has a decisive effect on the correct and fast growth of flower buds, while weak light either stops this process completely or retards it considerably (C o c k s u 11 and Hughes, 1972; M a c hin, 1997).

In Poland, the most unfavourable light conditions prevail from 1 November to 15 February. Solar radiation falls under a small angle, and this fact causes an additional loss of light under covers, because the radiation is reflected from window panes. Additionally, light radiation is dispersed by clouds. All-year-round culture with supplementary light in the autumn-winter period of insolation deficit is still rare ( $\mathrm{J} \mathrm{e} \mathrm{r} \mathrm{z} \mathrm{y} \mathrm{and}$ B orkowska, 2003; Jerzy et al. 2004). This results primarily from the high costs of electricity.

The aim of the research was to investigate seasonal changes of photoperiodic response and inflorescence quality in chrysanthemum from the Time group grown in controlled conditions all year round without supplementary lighting.

\section{MATERIALS AND METHODS}

The experiment was conducted using 4 cultivars of the chrysanthemum (Chrysanthemum $\times$ grandiflorum /Ramat./ Kitam) from the Time group: 'Cool Time', 'Dream Time', 'Energy Time', 'Quartz Time'. 
A detailed description of plants is shown in Table 1. Starting from 2 January 2002, on the second day of each successive month of the year rooted cuttings were planted into pots $14 \mathrm{~cm}$ in diameter, 5 cuttings per pot. The plants were grown in peat substrate with a $\mathrm{pH}$ of 5.5, mixed with PGMix and Radigen fertilizers. The pots with cuttings were placed in a soil bed in the greenhouse at a $30 \times 30 \mathrm{~cm}$ spacing in a diagonal pattern $\left(9\right.$ pots $\left.\mathrm{x} \mathrm{m}^{-2}\right)$. From the moment of potting, the plants were treated with a short day. In periods of naturally long days, the day was shortened to 10.5 hours through shading. No supplementary illumination was used from November to mid-February (a photoperiod of under 10 hours) to improve light conditions in the period of insolation deficit. In summer, when the night temperature outside the greenhouse exceeded $15^{\circ} \mathrm{C}$, the blackout covers opened 2 hours after sunset and closed 2 hours before sunrise to reduce the temperature inside. Real insolation over the research period is shown in Fig. 1, while Fig. 2 presents the temperatures of the greenhouse air. For the first few days after potting, the plants were sprinkled with water; later this practice was replaced with drip fertigation (EC of nutrient solution 1.8-2.0 mS $\times \mathrm{cm}^{-1}$ ). The plants were fed once, usually with $160 \mathrm{~cm}^{3}$ of the solution per pot, with the feeding frequency depending on weather conditions. The chrysanthemums were also fed with carbon dioxide.
The gas concentration was kept at 1.100-1.200 $\mu \mathrm{l} \times \mathrm{dm}^{-3}$ with closed ventilators, and at $550-600 \mu \mathrm{l} \times \mathrm{dm}^{-3}$ with opened ones.

Five days after potting, stem tips were pinched above the fifth leaf, counting from the base of the stem. The chrysanthemums were retarded using the preparation B-Nine $85 \mathrm{SP}$ at a concentration of $0.3 \%$. The treatment was applied first when lateral shoots (after pinching the main stem) attained a length of 10-15 mm. Two further treatments were given every 7-10 days. Because of severe retardation and weakening of growth of the plants, B-Nine was not applied in cycle 11 (planting on 2 November). For the same reason, all the cultivars from cycle 12 (planted on 2 December) were only treated with B-Nine once, when flower buds appeared on lateral shoots $5-7 \mathrm{~cm}$ long.

In the experiment the following features were studied: number of flower heads (developed and undeveloped) and size of flower heads assessed on the basis of measurement of the diameter of five biggest ones in a pot. Measurements and observations were carried out when the plants were at full bloom (half of all flower heads were fully opened). The measurement results were processed statistically using univariate analysis of variance. To evaluate the significance of differences among means at the $\alpha=0.05$ significance level, Duncan's test was employed.

Table 1.

Characteristics of chrysanthemum cultivars

\begin{tabular}{lclll}
\hline \multicolumn{1}{c}{ Cultivar } & $\begin{array}{c}\text { Nominal photoperiodic } \\
\text { response (days) }\end{array}$ & \multicolumn{1}{c}{ Flower type } & Flower colour & Growth vigour \\
\hline Cool Time & 52 & single & yellow & medium \\
Dream Time & 60 & anemone & white-yellow & small \\
Energy Time & 52 & single, spoon & red & medium high \\
Quartz Time & 49 & decorative & creamy yellow & small \\
\hline
\end{tabular}

Table 2.

Effect of cultivation time on the number of flower heads of four chrysanthemum cultivars

\begin{tabular}{lcccc}
\hline \multirow{2}{*}{$\begin{array}{c}\text { Beginning } \\
\text { of cultivation }\end{array}$} & Cool Time & Dream Time & Energy Time & Quartz Time \\
\cline { 2 - 4 } Jan 2, 2002 & $17.53 \mathrm{a}$ & $25.80 \mathrm{a}$ & $21.33 \mathrm{a}$ & $24.00 \mathrm{bc}$ \\
Feb 2, 2002 & $32.73 \mathrm{c}$ & $56.00 \mathrm{c}$ & $37.40 \mathrm{c}$ & $21.40 \mathrm{~b}$ \\
Mar 2, 2002 & $43.07 \mathrm{~d}$ & $94.27 \mathrm{e}$ & $46.60 \mathrm{~d}$ & $27.73 \mathrm{~d}$ \\
Apr 2, 2002 & $49.33 \mathrm{e}$ & $83.00 \mathrm{~d}$ & $47.27 \mathrm{~d}$ & $25.53 \mathrm{~cd}$ \\
May 2, 2002 & $60.00 \mathrm{f}$ & $85.67 \mathrm{~d}$ & $55.80 \mathrm{e}$ & $33.60 \mathrm{e}$ \\
Jun 2, 2002 & $49.40 \mathrm{e}$ & $99.87 \mathrm{f}$ & $61.60 \mathrm{f}$ & $41.87 \mathrm{f}$ \\
Jul 2, 2002 & $59.47 \mathrm{f}$ & $104.33 \mathrm{f}$ & $48.93 \mathrm{~d}$ & $50.53 \mathrm{~g}$ \\
Aug 2, 2002 & $83.00 \mathrm{~g}$ & $125.27 \mathrm{~g}$ & $67.00 \mathrm{~g}$ & $58.20 \mathrm{~h}$ \\
Sep 2, 2002 & $51.47 \mathrm{e}$ & $80.13 \mathrm{~d}$ & $35.67 \mathrm{c}$ & $33.60 \mathrm{e}$ \\
Oct 2, 2002 & $23.47 \mathrm{~b}$ & $30.87 \mathrm{a}$ & $26.47 \mathrm{~b}$ & $23.93 \mathrm{bc}$ \\
Nov 2, 2002 & $26.27 \mathrm{~b}$ & $47.40 \mathrm{~b}$ & $21.13 \mathrm{a}$ & $12.67 \mathrm{a}$ \\
Dec 2, 2002 & $23.33 \mathrm{~b}$ & $45.33 \mathrm{~b}$ & $23.80 \mathrm{ab}$ & $13.40 \mathrm{a}$ \\
\hline
\end{tabular}


Table 3.

Effect of cultivation time on the diameter of flower heads $(\mathrm{cm})$ of four chrysanthemum cultivars

\begin{tabular}{lcccc}
\hline \multirow{2}{*}{$\begin{array}{c}\text { Beginning } \\
\text { of cultivation }\end{array}$} & Cool Time & Dream Time & Energy Time & Quartz Time \\
\cline { 2 - 5 } Jan 2, 2002 & $7.19 \mathrm{~b}$ & $6.29 \mathrm{e}$ & $6.63 \mathrm{~b}$ & $7.21 \mathrm{c}$ \\
Feb 2, 2002 & $7.95 \mathrm{ef}$ & $6.50 \mathrm{f}$ & $7.67 \mathrm{~d}$ & $9.02 \mathrm{~h}$ \\
Mar 2, 2002 & $7.79 \mathrm{de}$ & $5.87 \mathrm{c}$ & $7.93 \mathrm{e}$ & $8.06 \mathrm{ef}$ \\
Apr 2, 2002 & $7.35 \mathrm{bc}$ & $6.07 \mathrm{~d}$ & $7.24 \mathrm{c}$ & $7.97 \mathrm{e}$ \\
May 2, 2002 & $7.54 \mathrm{~cd}$ & $5.73 \mathrm{c}$ & $7.13 \mathrm{c}$ & $8.53 \mathrm{~g}$ \\
Jun 2, 2002 & $5.31 \mathrm{a}$ & $4.43 \mathrm{a}$ & $5.42 \mathrm{a}$ & $5.41 \mathrm{a}$ \\
Jul 2, 2002 & $7.35 \mathrm{bc}$ & $5.38 \mathrm{~b}$ & $6.53 \mathrm{~b}$ & $8.28 \mathrm{fg}$ \\
Aug 2, 2002 & $7.23 \mathrm{~b}$ & $6.09 \mathrm{~d}$ & $7.23 \mathrm{c}$ & $9.17 \mathrm{~h}$ \\
Sep 2, 2002 & $8.78 \mathrm{~g}$ & $6.39 \mathrm{ef}$ & $7.89 \mathrm{e}$ & $8.19 \mathrm{ef}$ \\
Oct 2, 2002 & $7.20 \mathrm{~b}$ & $5.80 \mathrm{c}$ & $7.15 \mathrm{c}$ & $7.61 \mathrm{~d}$ \\
Nov 2, 2002 & $8.07 \mathrm{f}$ & $6.77 \mathrm{~g}$ & $7.63 \mathrm{~d}$ & $8.31 \mathrm{fg}$ \\
Dec 2, 2002 & $9.03 \mathrm{~g}$ & $7.43 \mathrm{~h}$ & $7.79 \mathrm{de}$ & \\
\hline
\end{tabular}

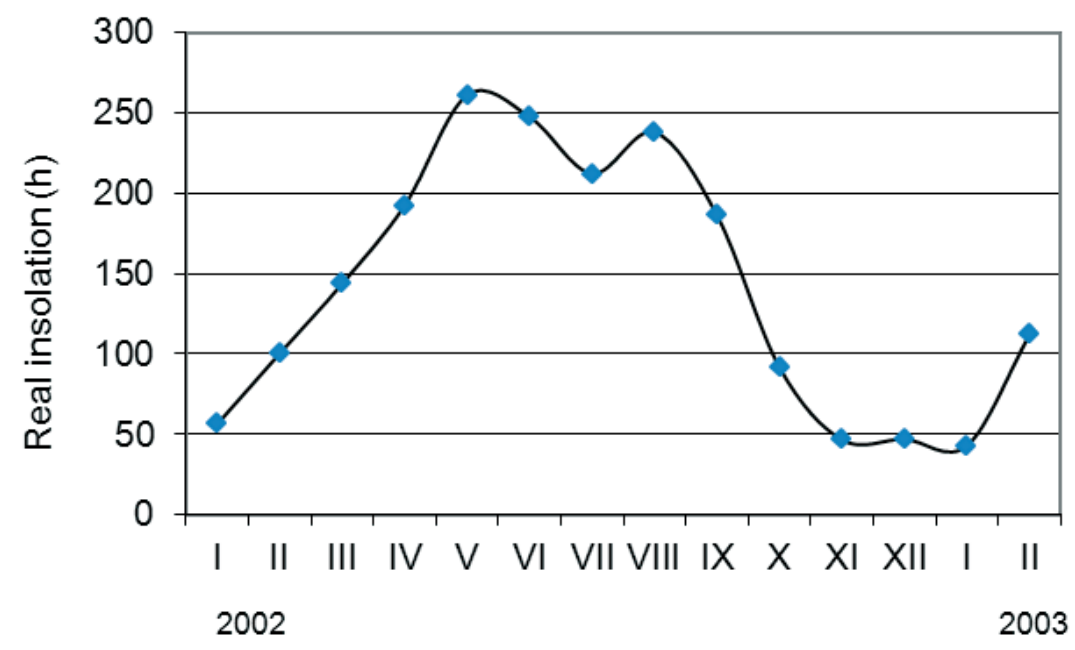

Fig. 1. Real insolation from January 2002 to February 2003.

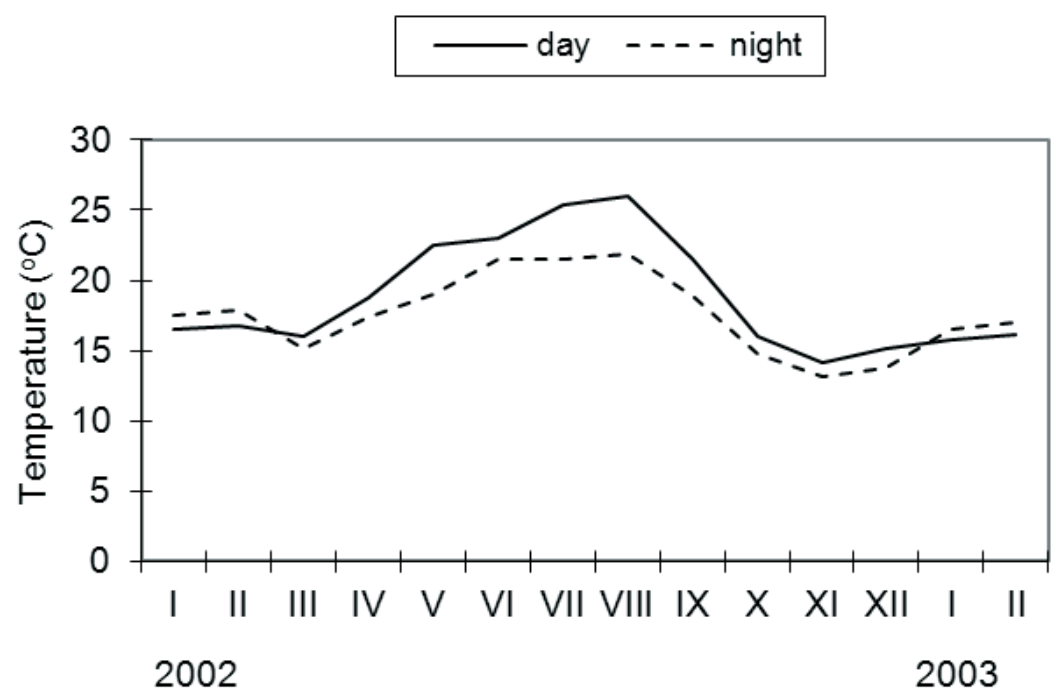

Fig. 2. Air temperature in the glasshouse from January 2002 to February 2003. 


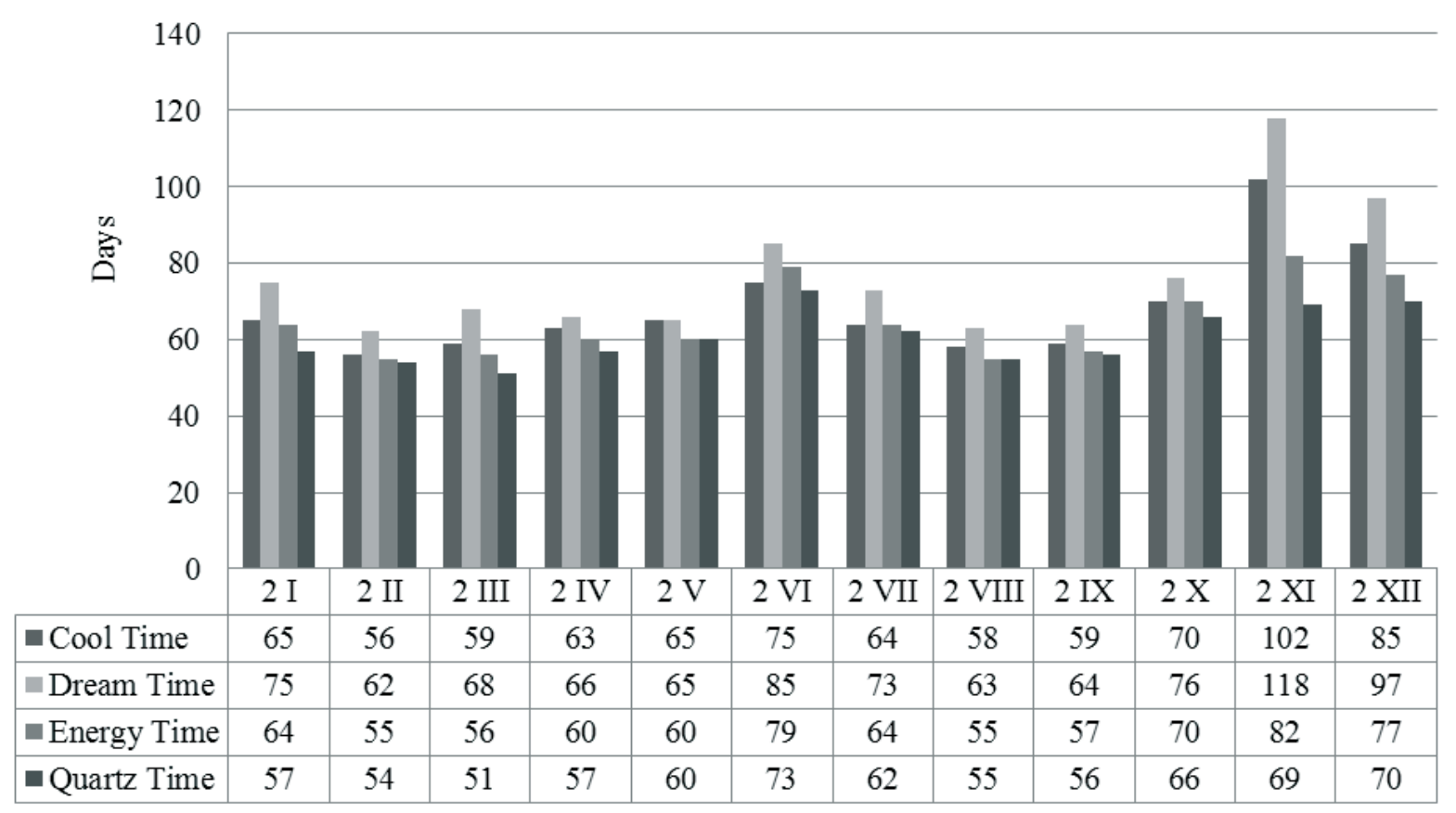

Fig.3. Photoperiodic response of chrysanthemums in dependence on potting time.

\section{RESULTS AND DISCUSSION}

Seasonal changes of photoperiodic response are presented in Fig. 3. The shortest photoperiodic responses of chrysanthemums 'Cool Time', 'Energy Time' and 'Quartz Time' were recorded in cycles starting in February or March and August or September. In case of 'Dream Time', the shortest photoperiodic responses were recorded in cycles starting in February - May and August or September.

Plants grown in the cycles starting in February to May and from July to September flowered after an average of two months. An exceptionally longer photoperiodic response was recorded in the cycle including the height of summer, i.e. planting in June, when the temperature during the whole growing cycle was very high. The same effect was observed in the last two cycles falling in the autumn-winter period of insolation deficit in Poland. Flowering was seriously retarded. The photoperiodic response was much longer than the nominal one, from $41 \%$ in case of 'Quartz Time' to 9697\% in case of 'Dream Time' and 'Cool Time' chrysanthemums. According to Lint and Heij (1987), the chrysanthemum grows faster at higher temperatures, but flower bud formation in short days is optimally fast at moderate temperatures, $17-21^{\circ} \mathrm{C}$. At night temperatures below $17^{\circ} \mathrm{C}$ and above $21^{\circ} \mathrm{C}$, bud formation is retarded. Cockshull and Kofranek (1994) claim that prolonged temperature of $32-35^{\circ} \mathrm{C}$ may stop chrysanthemum blooming altogether.

The results of the research on the effect of the planting date on the flowering of English varieties of chrysanthemums from the Time group (Cleangro Breeding) reported in this article turned out to be similar to those obtained by J e r z y and B ork ow s k a (2003) in their study of the rhythm of growth and flowering of American cultivars of chrysanthemums (Yoder Brothers Inc.), in all-year-round culture. In both experiments, the number and quality of inflorescences depended on light conditions and temperature changing over the year. In our experiments, the highest quality of bloom was attained by plants potted mostly between 2 March and 2 September and flowering from April - May to November (Tables 2, 3). Those plants developed the greatest number of flower heads and usually a typical, cultivar-specific colour of the flower.

Chrysanthemums 'Dream Time', 'Energy Time', 'Quartz Time' potted from 2 June to 2 July, i.e. in the period of the greatest heat, produced inflorescences with the smallest diameter. For 'Cool Time' chrysanthemums, this unfavourable period lasted from 2 April to 2 August. Temperatures prevailing in that time in the greenhouse significantly differed from the optimal ones and caused not only the above mentioned noticeable elongation of photoperiodic response, but also a significant deterioration of the quality of all investigated cultivars.

The effect of growing conditions on the growth and blooming of chrysanthemums was investigated also by other authors. C a r v a $\mathrm{l}$ h o et al. (2002) found that light conditions influenced flower bud removal, flower size and number of flowers in cut chrysanthemum. Nothnagl and Larsen (2002) found relationship between chrysanthemum flower head 
diameter and light conditions. Low light integrals had a retarding effect on flower growth resulting in smaller flowers. Also, the temperature affects all chrysanthemum flower characteristics, except for flower position within the plant. Higher temperatures increased the number of flowers per plant, mainly by increasing the number of flower buds, but decreased individual flower size (Carvalho et al. 2005). According to Karlss on and Heins (1992), the dry mass of chrysanthemum leaves increased with decreased light intensity, whereas the effect of day and night temperature seemed to be small. Le e et al. (2003) elaborated the expolinear growth equation for modelling cut chrysanthemum growth in year-round culture. However, further research on leaf area development in cut chrysanthemum is required to advance chrysanthemum crop growth prediction. The photoperiodic response of all cultivated chrysanthemum cultivars was always longer than the nominal one. Also, the quality of flower heads was very dependent on the time of cultivation. It is necessary to take this fact into account when planning an all-year-round production cycle.

\section{CONCLUSIONS}

1. In Polish climatic conditions, the shortest photoperiodic responses of chrysanthemums from the Time group were usually recorded in cycles starting in February or March and August or September. An exceptionally longer photoperiodic response was recorded in the cycle including the height of summer, i.e. planting in June, when the temperature during the whole growing cycle was very high, and from October to December, i.e. in the period of light shortage.

2. The highest number of flower heads was attained by plants potted mostly between 2 March and 2 September and flowering from the end of April to November. Those plants developed inflorescences with usually a typical, cultivar-specific colour of the flower heads.

3. Chrysanthemums grown in the period of the greatest heat produced flower heads with the smallest diameter.

\section{REFERENCES}

Carvalho, M.P.S, Heuvelink, E., van Kooten, O. 2002. Effect of light intensity, plant density, and flower bud removal on flower size and number in cut chrysanthemum. Acta Hortic. 593: 33-38.

Carvalho, M.P.S, Abi-Tarabay, H. and, Heuvelin k, E., 2005. Temperature affects chrysanthemum flower characteristics differently during three phases of the cultivation period. J. Hort. Sci. Biotechnol. 80(2): 209-216.
Cockshull K.E., Hughes A.P., 1972. Flower formation in Chrysanthemum morifolium: the influence of light level. J. Hort. Sci. 47: 113-127.

Cockshull K.E., Kofranek A.M., 1994. High night temperatures delay flowering, produce abnormal flowers and retard stem growth of cut-flower chrysanthemums. Sci. Hortic. 56: 217-234.

Karlss on, M.G., Heins, R.D., 1992. Chrysanthemum dry matter partitioning patterns along irradiance and temperature gradients. Can. J. Plant Sci. 72: 307-316.

Jerzy M., B orkowska J., 2003. Rhytmics of growth and flowering of Dendranthema grandiflora Tzvetev in the year-round culture. Zesz. Probl. Post. Nauk Roln. 491: 111-123.

Jerzy M., Breś W., Pawlak P., 2004. Supplementary lighting of pot chrysanthemums cultivated under low level of real insolation. Acta Scien. Pol. Hortorum Cultus, 3(2): 41-46 (in Polish).

Lee J.H., Goudriaan J., Challa H., 2003. Using the expolinear growth equation for modelling crop growth in year-round cut chrysanthemum. Ann. Bot. 92(5): 697-708.

Lint P.J.A.L. and de, Heij G., 1987. Effect of day and night temperature on growth and flowering of chrysanthemum. Acta Hortic. 19: 53-61.

Mach in B ., 1997. Pot chrysanthemum production. Grower Guide, 5: 3-74.

Nothnagl, M. and Larsen, R.U., 2002. The relationship between chrysanthemum flower diameter and light conditions in the greenhouse - a modelling approach. Acta Hortic. 593: 179-183.

\section{Sezonowe zmiany w reakcji fotoperiodycznej i jakości kwiatostanów chryzantemy (Chrysanthemum $\times$ grandiflorum /Ramat./ Kitam) uprawianej w szklarni w doniczkach}

\section{Streszczenie}

Celem pracy była ocena sezonowej reakcji fotoperiodycznej i jakości kwiatostanów chryzantem z grupy Time w uprawie całorocznej bez doświetlania. Cztery odmiany chryzantem uprawiano w 12 cyklach zaczynających się od drugiego dnia każdego kolejnego miesiąca. Pierwszy cykl rozpoczęto w styczniu. Od momentu sadzenia rośliny uprawiano w warunkach dnia krótkiego. W okresie naturalnego długiego dnia skracano go do 10,5 godziny przez zaciemnianie. Od listopada do połowy lutego (fotoperiod poniżej 10 godzin), a więc w okresie niedoboru światła nie stosowano żadnego doświetlania. W polskich warunkach klimatycznych najkrótszą reakcję fotoperiodyczną odnotowywano zwykle w cyklach rozpoczynających się 
w lutym lub marcu i sierpniu lub wrześniu. Wyraźnie dłuższą reakcję fotoperiodyczną stwierdzono w cyklach obejmujących środek lata tj. sadzenie od czerwca do lipca, gdy podczas dnia panowały wysokie temperatury oraz od października do grudnia czyli w okresie deficytu usłonecznienia. Najwyższą jakość kwiatostanów uzyskały rośliny sadzone między 2 marca i 2 września a kwitnące od kwietnia - maja do listopada. Rośliny te wytworzyły najwięcej kwiatostanów i najczęściej typowy dla odmiany kolor kwiatów. Chryzantemy sadzone od 2 czerwca do 2 lipca, czyli w okresie największych upałów, miały kwiatostany o najmniejszej średnicy. Dla odmiany 'Cool Time' najbardziej niekorzystny okres trwał od 2 kwietnia do 2 sierpnia. 